\title{
Klasifikasi Wajah Menggunakan Support Vector Machine (SVM)
}

\author{
Reyhan Achmad Rizal ${ }^{1)}$, Imron Sanjaya Girsang ${ }^{2)} \&$ Sidik Apriyadi Prasetiyo ${ }^{3)}$ \\ Prodi Teknik Informatika, Fakultas Teknologi dan ILKOM \\ Universitas Prima Indonesia \\ Medan, Indonesia \\ 1) reyhanachmadrizal1@gmail.com
}

\begin{abstract}
Abstrak
Klasifikasi wajah merupakan teknik yang dapat digunakan untuk membedakan karakteristik pola wajah seseorang. Sistem klasifikasi wajah adalah suatu aplikasi yang membuat sebuah mesin dapat mengenali wajah seseorang sesuai dengan citra wajah yang telah ditraining dan disimpan di dalam database mesin tersebut. Klasifikasi wajah sendiri dapat dilakukan dengan berbagai cara, salah satunya adalah menggunakan metode support vector machine (SVM). Penelitian ini dilakukan dengan sampling yang di ambil dalam variasi posisi pada sudut kemiringan subjek ($\left.90^{\circ},-70^{\circ},-45^{\circ},-25^{\circ},-5^{\circ}\right)$ dan $\left(+90^{\circ},+70^{\circ},+45^{\circ},+25^{\circ},+5^{\circ}\right)$ dengan ukuran citra 640x480. Sistem klasifikasi wajah didalam penelitian ini dibangun dengan menggunakan metode support vector machine (SVM) dan bahasa pemograman Matlap. Penelitian ini menghasilkan tingkat true detection $90 \%$ dan false detection 10\% dari jumlah sampel 200 subjek yang digunakan.
\end{abstract}

Keywords-Klasifikasi wajah, sudut kemiringan, SVM

\section{Pendahuluan}

Klasifikasi wajah merupakan teknik yang dapat digunakan untuk membedakan karakteristik pola wajah seseorang. Di dalam pengolahan citra teknik klasifikasi wajah sering digunakan di berbagai bidang permasalahan, salah satu contohnya adalah pengenalan kriminal, sistem security, identifikasi pelanggaran lalu lintas, klasifikasi gender dll. Wajah merupakan salah satu ukuran fisiologis yang paling mudah dan sering digunakan untuk membedakan identitas individu yang satu dengan yang lainnya, dikarenakan wajah adalah bagian dari tubuh manusia yang tidak dapat diduplikasi [11]. Sistem klasifikasi wajah adalah suatu aplikasi yang membuat sebuah mesin dapat mengenali wajah seseorang sesuai dengan gambar wajah yang telah ditraining dan disimpan di dalam database mesin tersebut [6]. Klasifikasi wajah sendiri dapat dilakukan dengan berbagai cara, salah satunya adalah menggunakan metode support vector machine (SVM).

Support vector machine (SVM) merupakan metode yang bekerja dengan cara mendefinisikan batas antara dua kelas dengan jarak maksimal dari data yang terdekat, jarak maksimal ini didapatkan dengan menemukan hyperplane (garis pemisah) terbaik pada input space yang diperoleh dengan mengukur margin hyperplane. Margin merupakan jarak antara hyperplane dengan titik terdekat dari masing-masing kelas [1][5].
Menurut [4] Secara umum, ada 4 tahapan dalam sistem klasifikasi wajah yaitu : akusisi citra wajah, preprocessing, ekstraksi fitur dan klasifikasi citra wajah. Dari keempat tahapan tersebut, tahapan ekstraksi fitur dan klasifikasi merupakan tahapan yang paling penting dalam sistem klasifikasi wajah. Ada banyak metode ekstraksi fitur yang telah dikembangkan untuk membangun sistem klasifikasi wajah. Dari semua metode tersebut, masing-masing memiliki kelebihan dan kelemahan. Ada metode yang bekerja dengan waktu komputasi yang cepat namun mengorbankan tingkat akurasi pengenalanya, dan ada pula metode dengan tingkat akurasi pengenalan yang tinggi namun membutuhkan waktu komputasi yang lama. Waktu komputasi dan tingkat akurasi pada sistem klasifikasi wajah, keduanya dipengaruhi oleh metode yang digunakan pada tahap ekstraksi fitur dan tahap klasifikasi. Sistem klasifikasi wajah sampai saat ini masih sangat rentan kesalahan dikarenakan sampling yang digunakan hanya dalam keadaan posisi tampak depan atau dengan posisi sudut $5^{\circ}$.

Menurut [8] support vector machine (SVM) merupakan metode perhitungan yang baik di dalam mendapatkan hasil klasifikasi dengan tingkat akurasi tinggi. Metode support vector machine (SVM) merupakan metode yang paling banyak digunakan untuk klasifikas wajah, dimana proses klasifikasi wajah 
dilakukan dengan mengklasifikasikan sebuah gambar yang sebelumnya melalui sebuah pengklasifikasi yang dibentuk dari data training [2]. Metode ini kemudian diterapkan pada sistem klasifikasi wajah didalam penelitian ini untuk mendapatkan karakteristik citra wajah subjek dengan variasi posisi wajah yang berbeda. Walaupun telah banyak dilakukan pengembangan terhadap sistem klasifikasi wajah namun hasilnya masih jauh dari kesempurnaan, terlebih sangat sedikit penelitian yang membahas tentang klasifikasi wajah berdasarkan variasi posisi wajah, variasi posisi wajah yang dimaksud pada penelitian ini adalah dengan sudut kemiringan subjek yang di mulai dari $\left(-90^{\circ},-70^{\circ},-45^{\circ}\right.$, $\left.-25^{\circ},-5^{\circ}\right)$ dan $\left(+90^{\circ},+70^{\circ},+45^{\circ},+25^{\circ},+5^{\circ}\right)[10]$.

Berdasarkan permasalahan yang telah dijabarkan sebelumnya, oleh karena itu untuk mengoptimalkan waktu komputasi tanpa harus mengorbankan tingkat akurasi pengenalan, di dalam penelitian ini peneliti mencoba membangun sistem klasifikasi wajah menggunakan bahasa pemograman matlap dengan metode support vector machine (SVM). Dengan harapan akan membantu untuk penelitian selanjutnya didalam klasifikasi wajah dengan jumlah sampel dan variasi posisi yang lebih banyak.

\section{A. Support vector machine (SVM)}

Support vector machine (SVM) merupakan metode klasifikasi yang diperkenalkan pertama kali oleh Vapnik pada tahun 1998. Pada dasarnya, metode ini bekerja dengan cara mendefinisikan batas antara dua kelas dengan jarak maksimal dari data yang terdekat. Untuk mendapatkan batas maksimal antar kelas maka harus dibentuk sebuah hyperplane (garis pemisah) terbaik pada input space yang diperoleh dengan mengukur margin hyperplane dan mencari titik maksimalnya. Margin merupakan jarak antara hyperplane dengan titik terdekat dari masing-masing kelas. Titik terdekat inilah yang disebut sebagai support vector machine (SVM). Support vector machine (SVM) dapat melakukan klasifikasi data yang terpisah secara linier (linearly separable) dan non-linier (nonlinear separable). Hyperline support vector machine (SVM) dapat dilihat pada gambar 1 di bawah ini [3][9]

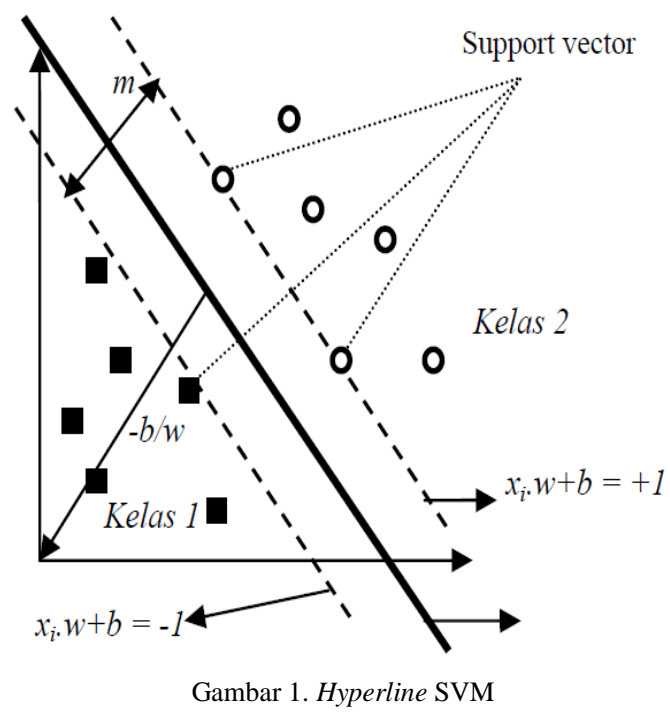

\section{Metode PenELITIAN}

\section{A. Datasheet}

Data yang digunakan dalam penelitian ini yaitu citra wajah dengan sudut kemiringan subjek yang di mulai dari ($\left.90^{\circ}, 70^{\circ},-45^{\circ},-25^{\circ},-5^{\circ}\right)$ dan $\left(+90^{\circ},+70^{\circ},+45^{\circ},+25^{\circ}\right.$, $+5^{\circ}$ ) dengan ukuran citra $640 \times 480$. Sampel penelitian yang digunakan dapat dilihat pada gambar 2 di bawah ini.
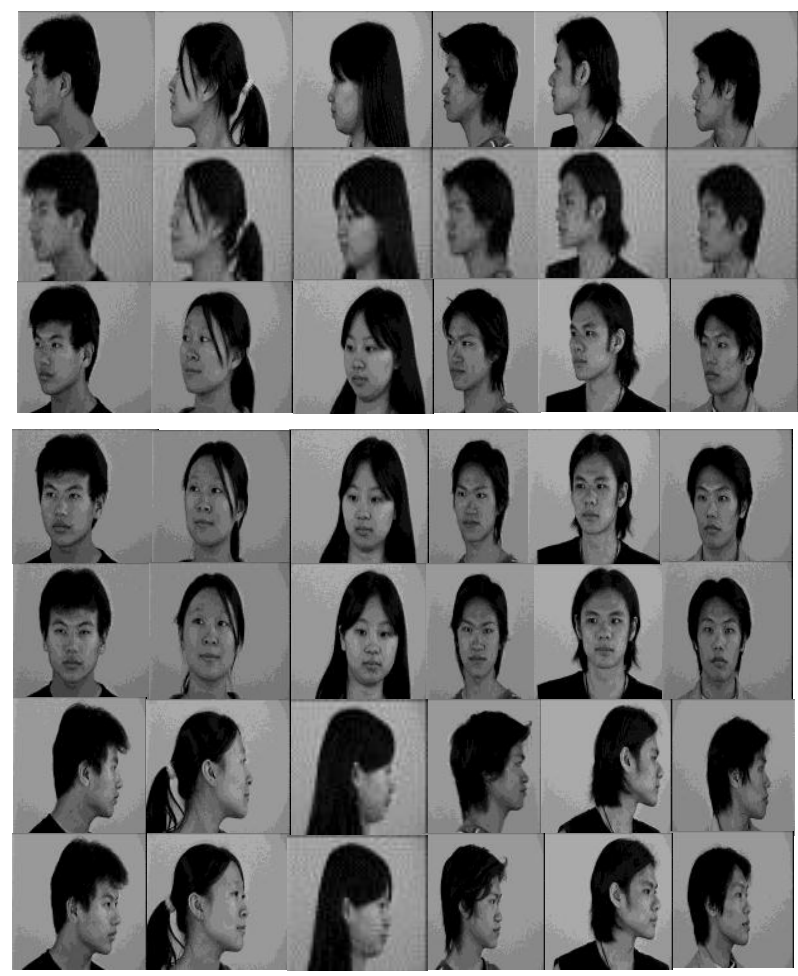


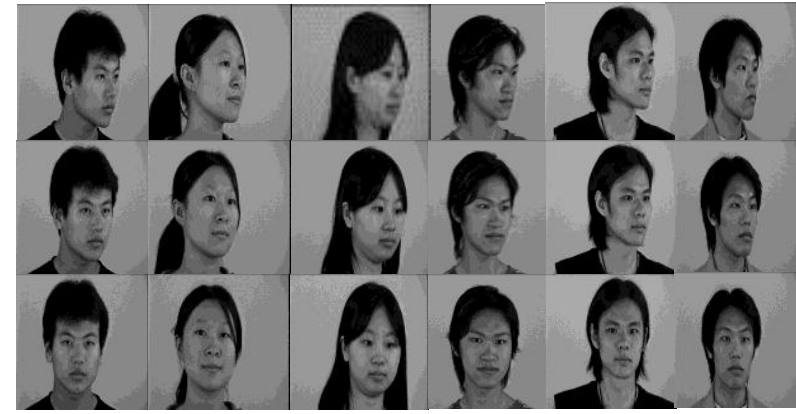

Gambar 2. Sampel penelitan yang digunakan

Pada gambar 2 di atas dapat dilihat contoh sampel penelitian sistem klasifikasi wajah yang digunakan, dengan sudut kemiringan subjek yang di mulai dari ($\left.90^{\circ},-70^{\circ},-45^{\circ},-25^{\circ},-5^{\circ}\right)$ dan $\left(+90^{\circ},+70^{\circ},+45^{\circ},+25^{\circ}\right.$, $+5^{\circ}$ ) pada citra $640 \times 480$. Adapun proses yang dilakukan setelah sistem menerima inputan akan dilanjutkan mengekstraksi fitur dan di hitung menggunakan support vector machine (SVM) selanjutnya model disimpan di dalam database untuk dijadikan sebagai pola acuan dalam menentukan hasil klasifikasi wajah.

\section{B. Langkah Penelitian}

Langkah penelitian secara umum yang dibangun dalam penelitian ini dapat dilihat pada Gambar 3 dibawah ini :

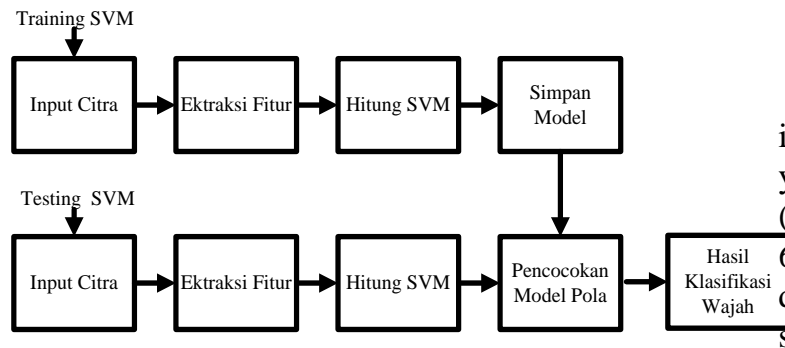

Gambar 3. Langkah penelitian secara umum

Pada Gambar 3 di atas dapat dilihat dua buah proses yang dilakukan yaitu proses training dan proses testing, pada proses training sistem menerima inputan citra selanjutnya dilakukan ektraksi fitur dan dihitung menggunakan support vector machine (SVM) hasil perhitungan di simpan di dalam database, sedangkan pada tahapan testing setelah sistem menerima inputan citra selanjutnya dilakukan ektraksi fitur dan dihitung menggunakan support vector machine (SVM) kemudian dilanjutkan ketahapan pengklasifikasian model pola menggunakan support vector machine (SVM), jika pola mirip atau mendekati pola training maka output dari klasifikasi yaitu hasil klasifikasi wajah.

Langkah penelitan secara keseluruhan klasifikasi wajah yang dibangun didalam penelitian ini dapat dilihat pada Gambar 4 di bawah ini.

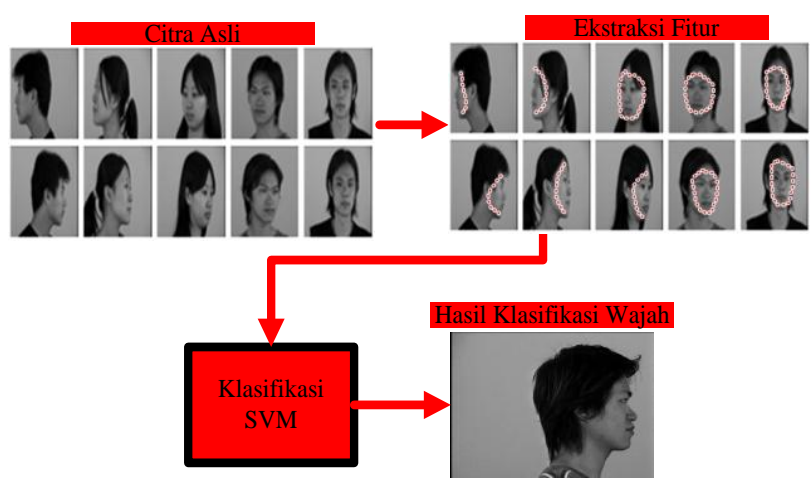

Gambar 4. Langkah penelitian secara keseluruhan

Pada gambar 4 di atas dapat dilihat langkah penelitian secara keseluruhan yaitu : setelah sistem menerima inputan citra selanjutnya dilakukan ektraksi fitur dan dihitung menggunakan support vector machine (SVM) kemudian dilanjutkan ketahapan pengklasifikasian model pola menggunakan support vector machine $(S V M)$, jika pola mirip atau mendekati pola training maka output dari klasifikasi yaitu hasil klasifikasi wajah.

\section{HASIL DAN PEMBAHASAAN}

Sampel wajah yang digunakan didalam penelitian ini adalah 200 sampel pada sudut kemiringan subjek yang di mulai dari $\left(-90^{\circ},-70^{\circ},-45^{\circ},-25^{\circ},-5^{\circ}\right)$ dan $\left(+90^{\circ},+70^{\circ},+45^{\circ},+25^{\circ},+5^{\circ}\right)$ dengan ukuran citra 40x480. Jumlah sampel dari 200 sampel, 60\% digunakan sebagai data training dan $40 \%$ digunakan sebagai data testing. Hasil unjuk kerja sistem keseluruhan klasifikasi wajah menggunakan support vector machine (SVM) dapat dilihat pada tabel 1 dibawah ini :

Tabel 1. Hasil unjuk kerja sistem klasifikasi wajah keseluruhan

\begin{tabular}{|c|c|c|c|c|c|c|c|c|c|c|}
\hline SVM & $S 1$ & $S 10$ & $S 2$ & $S 3$ & $S 4$ & $S 5$ & $S 6$ & $S 7$ & $S 8$ & $S 9$ \\
\hline$S 1$ & 0.63 & 0.00 & 0.00 & 0.00 & 0.00 & 0.00 & 0.38 & 0.00 & 0.00 & 0.00 \\
\hline$S 10$ & 0.00 & 1.00 & 0.00 & 0.00 & 0.00 & 0.00 & 0.00 & 0.00 & 0.00 & 0.00 \\
\hline$S 2$ & 0.00 & 0.00 & 0.63 & 0.38 & 0.00 & 0.00 & 0.00 & 0.00 & 0.00 & 0.00 \\
\hline$S 3$ & 0.00 & 0.00 & 0.00 & 1.00 & 0.00 & 0.00 & 0.00 & 0.00 & 0.00 & 0.00 \\
\hline$S 4$ & 0.00 & 0.00 & 0.00 & 0.00 & 0.88 & 0.00 & 0.00 & 0.13 & 0.00 & 0.00 \\
\hline
\end{tabular}




\begin{tabular}{||l|l|l|l|l|l|l|l|l|l|l|}
\hline S5 & 0.00 & 0.00 & 0.00 & 0.13 & 0.00 & 0.88 & 0.00 & 0.00 & 0.00 & 0.00 \\
\hline S6 & 0.00 & 0.00 & 0.00 & 0.00 & 0.00 & 0.00 & 1.00 & 0.00 & 0.00 & 0.00 \\
\hline $\boldsymbol{S 7}$ & 0.00 & 0.00 & 0.00 & 0.00 & 0.00 & 0.00 & 0.00 & 1.00 & 0.00 & 0.00 \\
\hline $\boldsymbol{S 8}$ & 0.00 & 0.00 & 0.00 & 0.00 & 0.00 & 0.00 & 0.00 & 0.00 & 1.00 & 0.00 \\
\hline $\boldsymbol{S 9}$ & 0.00 & 0.00 & 0.00 & 0.00 & 0.00 & 0.00 & 0.00 & 0.00 & 0.00 & 1.00 \\
\hline
\end{tabular}

Pada tabel 1 dapat dilihat hasil testing klasifikasi wajah menggunakan support vector machine (SVM), hasil testing pada sampel 1 mampu mengenali $(63 \%)$, sampel $2(63 \%)$, sampel $3(100 \%)$, sampel $4(88 \%)$, sampel 5 (88\%), sampel $6(100 \%)$, sampel $7(100 \%)$, sampel 8 (100\%), sampel 9 (100\%), sampel 10 (100\%). Dengan rata-ratanya adalah True Detection $90 \%$ dan False Detection $10 \%$. Grafik hasil klasifikasi wajah menggunakan support vector machine (SVM) dapat dilihat pada gambar 5 dibawah ini.

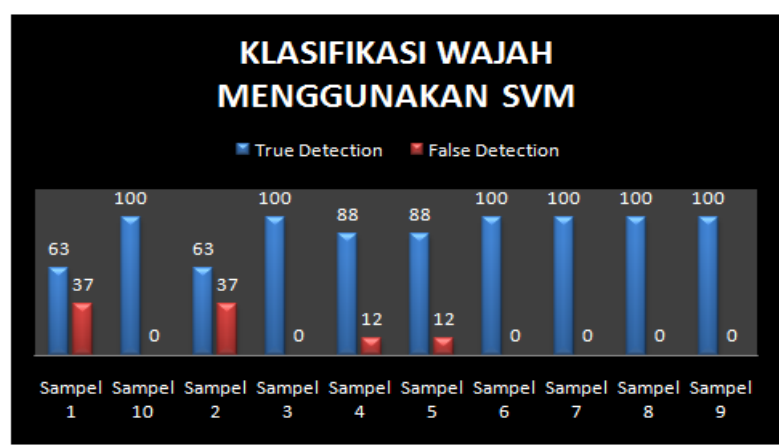

Gambar 5. Hasil klasifikasi wajah menggunakan SVM

\section{SIMPULAN}

Hasil penelitian menunjukan tingkat akurasi di dalam klasifikasi wajah menggunakan metode support vector machine (SVM) sangat baik dengan rata-rata true detection $90 \%$ dan false detection $10 \%$. Keunggulan metode support vector machine (SVM) yaitu memiliki kemampuan generalisasi yang tinggi tanpa persyaratan pengetahuan tambahan, bahkan dalam dimensi yang tinggi dari ruang input sehingga proses komputasinya memiliki tingkat akurasi yang tinggi dan sangat hemat memori. Walaupun sangat baik dalam menyelesaikan permasalahan klasifikasi, support vector machine $(S V M)$ hanya dapat digunakan pada data yang bersifat linear saja, sehingga untuk dapat digunakan pada data non-linear maka support vector machine (SVM) harus dimodifikasi dengan menggunakan fungsi kernel.

\section{Daftar Pustaka}

[1] A. Muhammad, "Pengenalan wajah menggunakan svm multi kernel dengan pembelajaran yang bertambah" , "JOIN (Jurnal Online Informatika) Volume 2 No. 2. 84-85, Desember 2017.

[2] B. Saeed, A. Akbarzadeh, M. Zarrabi, "using pca combined svm in the classification of eutrophication in dez reservoir (iran)", "Environmental Engineering and Management Journal Vol. 16, No. 9,. 2140-2141, September 2017.

[3] C. Ivo Rally Drajana, "Metode support vector machine dan forward selection prediksi pembayaran pembelian bahan baku kopra, "ILKOM Jurnal Ilmiah Volume 9 Nomor 2. 116-117, Agustus 2017.

[4] Fandiansyah, J. Yusmah Sari, I. Purwanti Ningrum, "Pengenalan wajah menggunakan metode linear discriminant analysis dan $\mathrm{k}$ nearest neighbor, "ULTIMATICS Vol.IX, No.1. 1-2, Juni 2017.

[5] M. Debasmita, T. Oommen, A. Agarwal, S. K.Mishra, "Application and analysis of support vector machine based simulation for runoff and sediment yield", "Elzevier. 527-531, April 2009.

[6] M. Jozsef, R. Szabolcsi, "Support vector machine and fuzzy logic", "Acta Polytechnica Hungarica Vol.13, No. 5.207-210, 2016.

[7] Muhathir, "Klasifikasi ekspresi wajah menggunakan bag of visual words", "JITE, Vol. 1. 74-75, Januari 2018.

[8] P. Navin, Y. Singh, "Support vector machines for face recognition", "IRJET Volume: 02 Issue: 08. 1521, November 2015 .

[9] R. Ahmad Mustafa, A. Akbar Fitrawan, Supria, "Pengenalan wajah menggunakan implementasi t-shape mask pada two dimentional linear discriminant analysis dan support vector machine", "Jurnal Buana Informatika Volume 7, Nomor 1. 3-4, Juli 2015.

[10] S. Aries, "Pengenalan wajah menggunakan metode viola-jones dan eigenface dengan variasi posisi wajah berbasis webcam", "TechnoXplore jurnal ilmu komputer \& teknologi informasi Vol 1 No:2. 19,Oktober 2016.

[11] Salamun dan F. Wazir, "Rancang bangun sistem pengenalan wajah dengan metode principal component analysis", "Jurnal Teknologi dan Sistem Informasi UNIVRAB Vol. 1 No. 2. 5960, Agustus 2016. 